\title{
English Professional Curriculum Reform from the Perspective of Students' Needs under the Background of Socialization of NMET Junling Yan
}

\author{
School of Foreign Languages, Chifeng University, Chifeng, Inner Mongolia, China
}

13947659118@126.com

Keywords: Socialization of NMET; Students' needs; English professional curriculum reform

\begin{abstract}
Under the background of socialization of NMET, college English major courses also need to adjusted to a certain degree. To meet students' needs, universities should add in appreciation courses to cultivate students' innovation and enhance students' ability of listening and speaking. On teachers' guidance work, teachers should arouse students' enthusiasm in class, inspire students' divergent thinking and strengthen students' self-confidence. Use the reform of college English professional courses to cope with the changes of the social needs of the reform of socialization of NMET in order to cultivate talents with comprehensive ability so that they can better serve the society and meet the needs of the society.

Since the implementation of the college entrance examination system, according to China's actual national conditions and personnel training, in constant exploration and study, in order to improve examinees comprehensive quality and improve China's comprehensive national strength, our country has been in constant reform of college entrance examination system. In recent years, much attention has been paid to English college entrance examination system. In the third plenary session of the communist party of China 18, the suggestion is that we should explore English university entrance exam for social tests. Social examination refers to students from the school system, through social institutions to participate in the examination. They can take an examination of more in order to get the best result which is included in the university entrance exam grades. The system reform is both an opportunity and a challenge for college English teaching and development. Under the background of socialization of NMET, university English major curriculum not only needs keeping pace with the times, to a certain reform, but also meets students' needs[1]. To really implement this, we must be from students' perspective to explore and analyze their potential advantages and disadvantages in the face of socialization of NMET[2]. Through a certain curriculum adjustment, cultivate new talents with all-round development so as to meet social demands[3].
\end{abstract}

\section{Students' First Need - Solid Foundation under the Background of Socialization of NMET}

The reform of English college entrance examination put forward that examination scope is limited to understanding and mastering of basic knowledge. According to the reform of this new system, NMET becomes simple and candidates only need to be flexible in understanding and applying basic knowledge. Under the background of socialization of NMET, English majors may have solid English foundation[4]. If they choose to be educators after graduation, their solid English foundation can satisfy the needs of the society. In fact, solid English foundation is the fundamental requirement of each English major although there are still some graduations who have not reach this requirement. Because one word may have different meanings in different contexts, it is not easy to master the full usage of every word. According to the fact on the reform of the course, it requests students to consolidate and practise basic vocabulary, syntax and grammar, familiar with their meanings and rules on the existing basis and in the process of learning. What is worth mentioning is that, in English-speaking countries, the commonly used words are only around 3000. Thus, if language learners can really master these basic words, their English learning will naturally reach a new level[5].

From the perspective of students' needs, it is necessary to use solid foundation as a criterion for 
professional curriculum reform[6]. For example, in comprehensive English courses, teachers can let each student analyze classic sentences in the text and use new words to make sentences one by one. According to past actual situations, many students in comprehensive English classes cannot totally understand what teachers are teaching in class and the knowledge which is involved in the textbooks. Because text pages are long and class time is short, most students are still unable to understand sentence patterns and do not know how to use words properly after class. Therefore, it is necessary to let students participate in class more actively, do more preparations before class and discuss sentence patterns which cannot be understood by themselves with their classmates in class. Teachers should pick key parts of articles, explain them clearly and let students make sentences to practise them repeatedly in order to make every student understand and master all of these points and vocabulary to achieve the effect of solid foundation. At the same time, learning of English grammar is also important, which is the key factor to have the good foundation. A lot of students' grammatical knowledge before entering a university cannot match university learning categories. Good English basic knowledge requires students to have a clear syntax structure in their minds, if they want to do this, they must deepen grammar courses[7]. Such as courses in understanding of English grammar, using a classic sentence pattern as an example and analyzing sentence structures and grammar deeply let students fill their own grammar holes and learn new difficult grammar points on the basic of understanding and combining with the memory of what they have learned in class to practise sentence grammar points and to help students remember more firmly. Having good grammar foundation also can help students better understand difficulties of minor courses slightly and be more interested in learning difficulties in teaching materials.

\section{Students' Needs of Listening and Speaking Training under the Background of Socialization of NMET}

Because the English college entrance examination system was to train students how to have a high mark in exams in the past, fixed mode system made students only have abilities to cope with the college entrance examination questions, but they could not flexibly use English in a real world, which was proved by the common phenomenons of dumb English and deaf English. With deepening the reform of NMET, English as a language, its communication function is more and more obvious. One purpose of the reform of socialization of NMET is to make students escape from such a state and strengthen the ability of practical application[8]. In Beijing, the reform of English college entrance examination, listening comprehension has been increased to 50\%, which can be seen that it puts emphasis on the communicative and practical English. In this trend, it drives English major students to improve the abilities of listening and speaking and improve communication ability, which can be treated as a communication tool in an actual life smoothly. Many students' listening and speaking abilities are relatively weak. Because of the particularity of English major, schools cannot provide absolute native language environment and the opportunities to practice are very few, so the curriculum might be designed to compensate for this loss.

About listening, only the part of in English audio-visual course practices is not enough. Teachers should give students some assignments and look for some modest dictation contents to let students do listening practices. Then, teachers gradually increase difficult level and explain the part which students can not understand the contents of the class. At the same time, teachers can put interesting English videos without subtitles ten minutes each day to improve students' interests in listening, such as apple company's conference, or the award ceremony of the Nobel Prize. At the same time of cultivating interests and practising listening abilities, it can also widen the vision. Teachers should avoid only applying listening teaching material contents. Sometimes it is easy to make students produce boring feelings. Also, teachers can find some listening materials, like VOA or BBC, in order to arouse the enthusiasm of students' learning. In addition, speaking, due to the lack of the language environment, opportunities for students to speak English are very few[9]. For students, the less they speak, the more difficult they open their mouths. In such cases, on the one hand, students need oral English teachers to fully interact in class, intense interesting topic discussions and mobilize the classroom atmosphere to encourage students to speak and think more. 
On the other hand, they need teachers to cooperate with other departments, like as far as possible to communicate with students using English totally in class. This not only increases students' chances to practise oral English, but also practices listening skills. It is equivalent to provide students with the language environment, which can very effectively cultivate students' communicative competence. Schools should also carry out some English extracurricular activities, for example, traditional English corners. Students can learn English in the relaxing situation. Schools can also carry out English debating competitions which enhance students' abilities and their oral English will be greatly improved.

\section{Students' Need of Cultivating Innovative Thinking under the Background of Socialization of NMET}

The socialization reform of NMET pointed out that the selection mode of the ancient board hindered the development of students' innovative thinking and at the same time students should escape from the old examination mode and strengthen creative ability. This is also the disadvantage of Chinese education system. Now the cultivation of students' creative thinking is still in progress. Chinese classroom model is that teachers are always speaking and students are always listening. The lack of analysis and evaluation on critical thinking in education goals makes most students not have the habit of independent thinking. A large part of students are resistant to criticism and exploratory work because they do not have a good idea to finish their homework. The system reform of NMET raises English teaching reflecting on these points. For example, students can't write without creative thinking, so that they may not have opportunities to practise English and this will hinder the progress of learning.

To cultivate students' innovative thinking, colleges and universities need to set some creative appreciation courses to guide and inspire students to think. This not only enriches their knowledge, but also broadens their horizons. Most of the answers in appreciation courses do not have a certain right or wrong to cultivate students' curiosity and remove students' fear of giving wrong answers. The most important is to highlight the importance to the logical thinking ability and encourage creative spirit. For example, Greek and Roman culture tell ancient Greek and Roman legends to students in the form of combining Chinese and English so that their curiosity will lead their discussion and thinking, and then let students to write a small article after class to put forward their own thinking without setting range direction. So repeatedly in this way, it not only expands students' thinking, but also improves writing practices. For example, Chinese classic culture translation is mainly to state Chinese ideas of Confucian and Taoist classic in both English and Chinese. Teachers can let students make a speech before class, combining Confucian ideas with their own feelings and teachers can also choose students to answer questions from time to time. Courses like this are a good way to promote students' independent thinking and improve their creative thinking. Actually, the socialization reform of NMET put forward greater scope and further goals[10]. By reforming the traditional teaching mode, cultivate students' ability of independent thinking and inspire students' innovative thinking. This curriculum can make students be in a constant state of thinking and absorb knowledge.

\section{Students' Need of Enhancing Learning Self-confidence under the Background of Socialization of NMET}

Many people think that the socialization of NMET is weakening the position of English in the field of education, but in reality otherwise. Reducing English scores and difficulties is to break the situation that one examination is a lifetime in the past and give students more broad space to develop and let students have more choices. However, public opinion makes a lot of students think that this reform means that the status of English declines and many students will face the plight of unemployment. Teachers' concept may correct students' mistakes in time to give the correct guidance and conduct a comprehensive analysis on them so that students have long-term vision to see the prospects of learning English and restore enthusiasm and confidence in learning English. As 
we all know, English is the world common language and is the most widely used in the world, which has unshakable position nowadays. Even with the passage of time and the progress of the society, it will become more and more important. Even if the status in NMET declines, there is still increasing demand for it in all sectors of society. English is still an important method of going abroad and learning others' excellent experience. Now many colleges and universities improve the quality of school-running. Professionals in all fields have started to use English teaching to cultivate new type talents with all-round development in order to provide a powerful condition for various fields of the country and the world market[11]. In this trend, the demand for English talents is only increased. As colleges and universities, the requests to English major students are stricter to develop talents who can satisfy the requirements of social pillars. As teachers, when they are imparting knowledge, they also need to give students' encouragement constantly because they are under many tangible invisible pressure. If they have no self-confidence, they can't face social huge challenges. Teachers must enhance students' self-confidence and let them have more expectations to their own learning and professional.

In such an era of information and globalization, English plays a vital role, not only which is confined to the tools of communication between human beings and the international politics, military, science and technology, culture, trade, transportation and other fields, but also which illustrates that English is an important tool of communication. Our country is in a development stage. No matter in which field, English, as a tool for our development, should not be despised. In such a big background of the internationalization, with the evolution of NMET, the implementation of English to meet the needs of the social development and social system. Under the influence of this, the setting of English professional courses is also more urgent. We need to consider this from students' perspective to satisfy students' demands as the standard for all-round reform. Also, we must adjust courses and teachers according to actual situation of schools. Reform for students and teachers is a huge challenge. It will also have a significant impact on English majors' employment problem in the future. Anyway, the reform of English college entrance examination system and the reform of English major curriculum are for the better serving students, making them well prepare for a career and going further in learning English. At the same time, they continue to provide English elites that can serve the society and contribute to the development and prosperity of the country.

\section{References}

[1] Zheng Caiyun and Chen Shugen. Socialization of the College Entrance Examination Question Analysis [J]. Journal of Beijing Industrial Vocational and Technical College, (2009)(7) : 143-146

[2] Li Chengwei. Pros and Cons about NMET Socialization [J]. Journal of Exam Weekly, (2014) (10) : 4

[3] Li Tao. The Socialization of the College Entrance Examination Study [J]. Modern Education Science, (2013)(2) : 5-10

[4] Han Huiqing.College English Teaching Reform Ideas [J]. Journal of Luoyang Normal College, ( 2003) (3) : 113-115

[5] He Qixin, Yin Tongsheng, etc. Several Opinions on Reform of the Foreign Language Professional Undergraduate Course Education [J]. Foreign Language Teaching and Research, (1999) (1) : 24-28

[6] Cheng Xiaotang. Examination is not the natural enemies of the new curriculum - on the new curriculum under the background of the relationship between teaching and evaluation thinking [J]. People's Education,( 2007).

[7] Jia Guodong. Multimedia Teaching to Promote New Ways of College English Teaching [J]. Foreign Language World, (1999)(2) : 30-35

[8] Ministry of Education. English Course Teaching [M]. Shanghai Foreign Language Education Press,(2007).

[9] Ministry of Education. Teaching Requirements for College English Courses [M]. Shanghai 
Foreign Language Education Press,(2007).

[10] Yan Ming. The Research on the Teaching Theory and Practice of ESP [M]. Heilongjiang University Press, (2008).

[11]Dai Weidong and Huang Ren.Changing Ideas, Comprehensively Promote the Reform of Foreign Language Teaching [J]. Journal of International Studies, (1997)(6) : 1-4 